\title{
First report of tomato brown rugose fruit virus infecting sweet pepper in Syria and Lebanon
}

\author{
Raied Abou Kubaa ${ }^{1}$ (D) Elia Choueiri ${ }^{2} \cdot$ Khaled Heinoun $^{3} \cdot$ Fabrizio Cillo $^{1} \cdot$ Maria Saponari $^{1}$
}

Received: 20 September 2021 / Accepted: 15 October 2021 / Published online: 25 October 2021

(c) Società Italiana di Patologia Vegetale (S.I.Pa.V.) 2021

Keywords ToBRFV $\cdot$ Syria $\cdot$ Lebanon $\cdot$ Real-time RT-PCR

After the first outbreak of tomato brown rugose fruit virus (ToBRFV) in tomato in Jordan (Salem et al. 2016), this virus has been reported from other neighboring countries and worldwide. In early 2020, virus-like symptoms consisting in chlorosis, mosaic and leaves discolorations accompanied with brown stems and fruit deformation were observed on greenhouse-cultivated sweet pepper plants in the coastal regions of Syria (Tartous) and Lebanon (Byblos). A total of 40 symptomatic and 20 asymptomatic plants were sampled in different sites in both countries and tested for ToBRFV by real-time RT-PCR using CaTa28/CSP1325 primers and probes (diagnostic protocol PM 7/146, EPPO Bulletin 2021). ToBRFV was found in 44 samples including all symptomatic ones. Furthermore, RT-PCR using specific primers ToBRFV-F5722/ToBRFV-R6179 amplifying a 458-bp fragment of the coat protein gene (Panno et al. 2019) confirmed the identification of ToBRFV. All the samples tested negative for tomato spotted wilt virus, pepino mosaic virus and cucumber mosaic virus in RT-PCR. To confirm the specificity of the amplified DNA, one representative RTPCR amplicon from each country was sequenced in both directions. Sequences were deposited in GenBank under the accession numbers OU600529 and OU600530 for the Syrian and Lebanese isolates, respectively. Bioinformatics and BLAST analysis of the sequenced amplicons showed 99.78\% similarity between the Syrian and the Lebanese isolates and $99.56 \%$ nucleotide identity with TBRFV isolate

Raied Abou Kubaa

raied.aboukubaa@ipsp.cnr.it

1 CNR Istituto Per La Protezione Sostenibile Delle Piante (IPSP), UOS Bari, Italy

2 Department of Plant Protection, Lebanese Agricultural Research Institute, Tal Amara, P.O. Box 287, Zahlé, Lebanon

3 Ministry of Agriculture and Agrarian Reform, Department of Plant Protection, Damascus, Syria
Ant-Pep (MT002973.1) from Turkey. This is the first report of ToBRFV infecting sweet pepper plants in Syria and Lebanon.

\section{Declarations}

Conflict of interest The authors declare that they have no conflict of interest from this research, and that it doesn't contain any studies with human participants or animals.

\section{References}

EPPO Bulletin (2021) PM 7/146 (1) Tomato brown rugose fruit virus 51(2):346. https://doi.org/10.1111/epp.12761

Panno S, Garuso AG, Davino S (2019) First report of Tomato brown rugose fruit virus on tomato crops in Italy. Plant Dis 103(6):1443. https://doi.org/10.1094/PDIS-12-18-2254-PDN

Salem N, Mansour A, Ciuffo M, Falk BW, Turina M (2016) A new tobamovirus infecting tomato crops in Jordan. Adv Virol 161(2):503-506. https://doi.org/10.1007/s00705-015-2677-7

Publisher's Note Springer Nature remains neutral with regard to jurisdictional claims in published maps and institutional affiliations. 